\title{
Sheep gain and species diversity: In sandy grassland, Inner Mongolia
}

\author{
HA-LIN ZHAO, SHENG-GONG LI, TONG-HUI ZHANG, TOSHIYA OHKURO, AND RUI-LIAN ZHOU
}

\begin{abstract}
Authors are Professor, Postdoctoral Research Associate, Associate Professor, Assistant Professor and Associate Professor. Ha-Lin Zhao and Tong-Hui Zhang and Rui-Lian Zhou are located at the Cold and Arid Regions Environment and Engineering Research Institute (CAREER), Chinese Academy of Sciences, Lanzhou 730000, China; Sheng-Gong Li is located at Department of Biology, University of Utah, Salt Lake City, Utah 84112' USA; and Toshiya Ohkuro is located at National Institute for-Agro-Environental Sciences, Tsukuba 305-8604, Japan.
\end{abstract}

\section{Abstract}

A grazing experiment was conducted from 1992 to 1996 at a sandy grassland in the Horqin sandy land, located in the northeastern part of China. The grassland had been grazed by sheep for many years before the experiment at an intensity of $\mathbf{4 . 5}$ sheep $\mathrm{ha}^{-1}$. The experiment consisted of $\mathbf{4}$ grazing treatments: no grazing $\left(0\right.$ sheep ha $\left.^{-1}\right)$, light grazing ( 2 sheep ha $\left.^{-1}\right)$, moderate grazing ( 4 sheep $\left.\mathrm{ha}^{-1}\right)$ and overgrazing $\left(6\right.$ sheep $\left.\mathrm{ha}^{-1}\right)$. Plant species diversity, plant biomass, soil properties, and sheep liveweight under various grazing treatments were examined. Overgrazing resulted in considerable decreases in both species diversity and plant biomass. As a result, sheep liveweight gain decreased significantly in the last 3 years of the experiment in the overgrazing treatment. No grazing and light grazing treatments had higher species diversity as well as higher biomass production than moderate grazing and overgrazing treatments. The results indicate that light sheep grazing is sufficient for the recovery of overgrazed grassland in this region and for the maintenance of plant species diversity. The proper grazing intensity should be 2-3 sheep or sheep equivalents per hectare for the sandy grassland in Inner Mongolia.

Key Words: grazing intensity, species diversity, desertification, China

There is about $3.9 \times 10^{5} \mathrm{~km}^{2}$ of desertified land in China of which $28.3 \%$ is caused by overgrazing (Wang 2000). Overgrazing is the primary factor leading to grassland desertification in the Horqin sandy land, Inner Mongolia, which is one of the desertification-threatened areas in the northeastern part of China (Zhu and Chen 1994). The total area of the Horqin sandy land is $42,300 \mathrm{~km}^{2}$, of which about one third was desertified from 1975 to 1987 at an annual rate of $1,142 \mathrm{~km}^{2} \mathrm{y}^{-1}(\mathrm{Hu}$ 1996). Efforts have been made to monitor the progression of desertification in this area via remote-sensing techniques combined with field investigation to understand the relationship between desertification and long-term environmental change (Wang 2000). However, little information is available on the mechanism underlying grassland desertification caused by overgrazing in this area

Research was funded by one of the China National Key Projects for Basic Scientific Research (TG2000048704). Authors wish to thank 2 anonymous reviewers for their critical review and comments on drafts of this manuscript.

Manuscript accepted 14 Jul. 03.

\section{Resumen}

De 1992 a 1996 se condujo un experimento de apacentamiento en un pastizal de arenoso en los arenales de Horqin, localizados en el nordeste de China. El pastizal había sido apacentado por ovinos por muchos años antes del experimento a una intensidad de 4.5 borregos ha $^{-1}$. El experimento consistió de 4 tratamientos de apacentamiento: no apacentamiento ( 0 borregos $\left.\mathrm{ha}^{-1}\right)$, apacentamiento ligero ( 2 borregos $\mathrm{ha}^{-1}$ ), apacentamiento moderado (4 borregos ha- ${ }^{-1}$ ) y sobreutilizado (6 borregos ha ${ }^{-1}$ ). Se examinó la diversidad de especies vegetales, la biomasa vegetal, las propiedades del suelo y e I peso vivo de los borregos bajo los tratamientos de apacentamiento evaluados. La sobreutilización resulto en una disminución considerable tanto de la diversidad de especies como de la biomasa vegetal. Como resultado, en el tratamiento de sobreutilización, la ganancia de peso vivo de los borregos disminuyo significativamente en los últimos 3 años del experimento. Los tratamientos sin apacentamiento y apacentamiento ligero tuvieron una diversidad de especies y producción de biomasa vegetal más altas que los tratamientos de apacentamiento moderado y sobreutilización. Los resultados indican que el apacentamiento ligero de ovinos es suficiente para recuperar los pastizales sobreutilizados de esta región y para el mantenimiento de la diversidad de especies vegetales. Para los pastizales arenosos de las tierras interiores de Mongolia la intensidad de apacentamiento apropiada debe ser de 2 a 3 borregos por hectárea o su equivalente.

(Li et al. 2000). We conducted a grazing experiment from 1992 to 1996 on a typical grassland in the Horqin sandy land. The objectives were to: 1 ) determine the responses of grassland to various grazing intensities in terms of species composition, biomass, and vegetation cover; 2 ) assess the grassland desertification processes under increasing grazing intensity; and 3) determine the optimal grazing intensity for the studied grassland.

\section{Materials and Methods}

\section{Study Area}

The study area is located in Naiman county $\left(42^{\circ} 55^{\prime} \mathrm{N}, 120^{\circ}\right.$ $42^{\prime} \mathrm{E}, 345 \mathrm{~m}$ a. s. 1.) in the eastern part of Inner Mongolia, China. Naiman is located in the southwestern end of the Horqin sandy land and belongs to the continental semi-arid monsoon climate in the temperate zone. The annual mean precipitation is $366 \mathrm{~mm}$ 
(the precipitation in the experiment period were 401, 320, 533, 347 and $350 \mathrm{~mm}$ from 1992-1996, respectively); the annual mean potential evaporation is $1,935 \mathrm{~mm}$, and the annual mean temperature is 6.8 ${ }^{\circ} \mathrm{C}$. Dominant plant species in the grassland included Pennisetum centrasiaticum tzvel., Phragmites communis Trin. Fund. Agrost, Leymus secalinus (Georgi) Tzvel, Setaria viridis (L.) Beauv, Aristida adscensionis $\mathrm{L}$. and Chloris virgata Swartz. Landscape in this region is characterized by dunes alternating with gently undulating lowland areas. The sandy soil consists mainly of coarse sand and silt.

\section{Experimental Design}

An open and level grassland area was selected in 1992. The mean grazing density for the experimental grassland was 4.5 sheep $\mathrm{ha}^{-1}$ before the experiment (Zhao 1998). The grassland was experiencing slight degradation due to overgrazing by sheep according to the classification criteria of desertification degree of Zhu (1998). A 5.3 ha padded area $(200 \times 263 \mathrm{~m})$ was fenced using cement piles and barbed wires and was further divided into 4 plots for various grazing treatments: overgrazing (6 sheep ha $\left.{ }^{-1}\right)$, moderate grazing (4 sheep ha $\left.{ }^{-1}\right)$, light grazing ( 2 sheep ha-1) and no grazing ( 0 sheep ha $\left.{ }^{-1}\right)$. Grazing started 1 June and ended on 30 September each year from 1992 to 1996.

\section{Data Collection and Analysis}

Six quadrats $\left(1 \times 1 \mathrm{~m}^{2}\right)$ per plot were randomly selected at the end of each month to investigate vegetation cover, mean canopy height, above- and belowground biomass, and species composition and their density. Additional 6 random quadrats per plot were selected at the beginning of each month and covered with wire-net cages $\left(1.5 \times 1.5 \times 1.5 \mathrm{~m}^{3}\right)$. Aboveground biomass was measured with the clipping method (all the green part 1 $\mathrm{cm}$ above the ground inside the quadrats were cut). The biomass samples were put into paper bags in the field, oven-dried at $85^{\circ} \mathrm{C}$ for 24 hours and weighed. Vegetation cover was visually estimated. Canopy height was the mean height of the plants inside the quadrats. Standing crop biomass was a biomass in the open quadrats at the end of September. Net primary productivity was standing biomass plus grazing biomass during the experiment period.

Soil cores were taken from the center of each quadrat at the depths of $0-10,10-20$ and $20-30 \mathrm{~cm}$ with an auger. Soil cores were transported to the lab and washed off
Table 1. Soil physical and chemistry properties in sandy grassland of Inner Mongolia as affected by grazing at the end of the 5 -year experiment. Values are means \pm SD. Values with the same letters are not significantly different at $P \leq 0.05$.

\begin{tabular}{|c|c|c|c|c|c|c|}
\hline \multirow[b]{2}{*}{ Treatments } & \multirow[t]{2}{*}{ Hardness } & \multicolumn{2}{|c|}{ Soil texture (\%) } & \multicolumn{2}{|c|}{ Soil nutrient $\left(\mathrm{g} \mathrm{kg}^{-1}\right)$} & \\
\hline & & Clay & Silt + Sand & $\mathrm{C}$ & $\mathrm{N}$ & \\
\hline No grazing & $1.4 \pm 0.4^{\mathrm{a}}$ & $7.3 \pm 0.8^{\mathrm{a}}$ & $92.7 \pm 0.8^{\mathrm{a}}$ & $2.54 \pm 0.2^{2}$ & $0.24 \pm 0.1^{\mathrm{a}}$ & $10.6^{2}$ \\
\hline Light grazing & $1.6 \pm 0.7^{\mathrm{a}}$ & $7.8 \pm 1.1^{\mathrm{a}}$ & $92.2 \pm 1.1^{\mathrm{a}}$ & $2.40 \pm 0.7^{\mathrm{a}}$ & $0.22 \pm 0.1^{\mathrm{a}}$ & $10.9^{\mathrm{a}}$ \\
\hline Mod. grazing & $2.3 \pm 0.9^{b}$ & $7.2 \pm 1.3^{\mathrm{a}}$ & $92.8 \pm 1.3^{\mathrm{a}}$ & $2.73 \pm 1.3^{\mathrm{a}}$ & $0.26 \pm 0.1^{\mathrm{a}}$ & $10.5^{\mathrm{a}}$ \\
\hline Overgrazing & $5.2 \pm 0.0^{c}$ & $6.9 \pm 1.4^{\mathrm{a}}$ & $93.1 \pm 1.4^{\mathrm{a}}$ & $1.73 \pm 1.2^{b}$ & $0.18 \pm 0.1^{b}$ & $9.6^{b}$ \\
\hline
\end{tabular}

sand with a $0.25 \mathrm{~mm}$ mesh screen for root biomass determination. The root samples were later oven-dried at $85^{\circ} \mathrm{C}$ for 24 hours and then weighed. At each plot, 60 soil samples of $0-5 \mathrm{~cm}$ depth were also collected using a auger in September of 1996. Soil samples were air-dried in a shady and cool place and then ground to pass through $1.0 \mathrm{~mm}$ and $0.25 \mathrm{~mm}$ mesh screens, respectively, for subsequent analysis of soil texture, $\mathrm{C}, \mathrm{N}$, and $\mathrm{C} / \mathrm{N}$ ratio. Soil surface hardness at 60 points of each plot was measured in September 1996 with a hardness meter (Yamanaka 07202301, Fujiwara Scientific Co. Ltd., Tokyo, Japan).

Before the beginning of the experiment of each year, and by the end of each month during the grazing period, weight of each sheep was weighed in the early morning over the grazing season.

Shannon-Wiener species diversity index $(H)$ was calculated for each plot (Shannon and Wiener 1949). The grazed biomass was the difference in the mean biomass between the quadrats with and without net-cages. Net primary productivity was computed as standing crop biomass at the end of September plus grazed biomass during grazing period. Monthly data were further averaged to get annual mean values. Multiple comparison and analysis of variance (ANOVA) were used to determine the differences among the treatments (Sokal and Rohlf 1995).

\section{Results}

\section{Soil Physical and Chemical \\ Properties}

Soil surface hardness increased with increasing grazing intensities (Table 1). The hardness of the overgrazing treatment was considerably higher than other grazing treatments. Soil texture was not significantly different among treatments ( $P$ > 0.05). Carbon content, nitrogen content and $\mathrm{C} / \mathrm{N}$ ratio of the top $5 \mathrm{~cm}$ of soil were not significantly different among no grazing, light grazing, and moderate grazing treatments $(P>0.05)$, but lower in the overgrazing treatment than others.

\section{Plant Diversity} Shannon-Weaver species diversity index $\left(H^{\prime}\right)$ was significantly higher than that in other treatments in the first 2 years of the experiment $(\mathrm{P}<0.05)$ (Fig. 1), but lower than that in other treatments after year 3 . The $H^{\prime}$ did not show significant
In the overgrazing treatment, the decreased sharply and was significantly

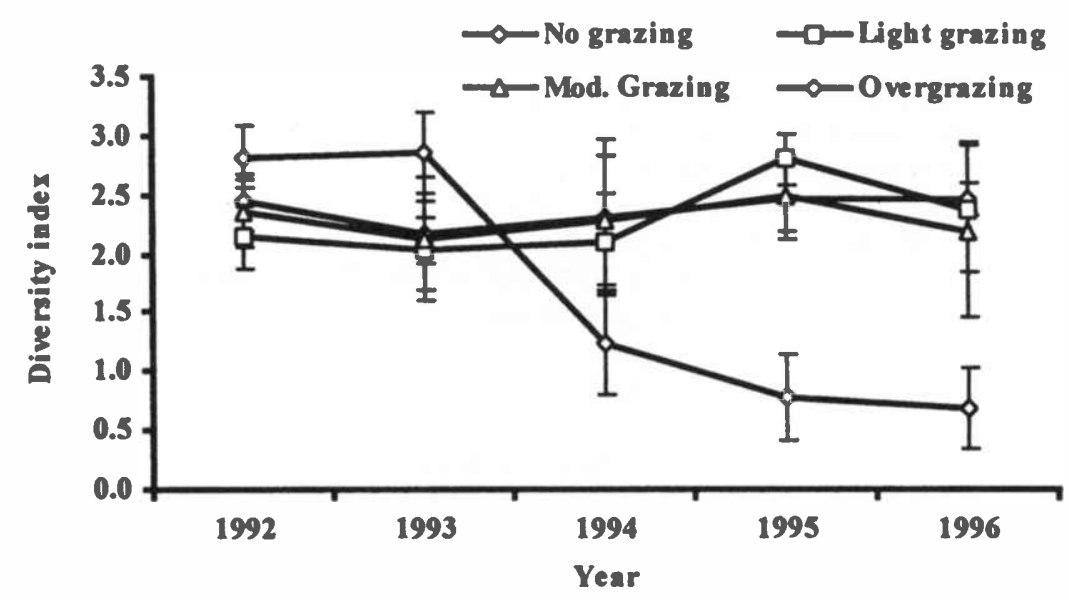

Fig. 1. Plant species diversity index in sandy grassland of Inner Mongolia from 1992 to 1996 as affected by different grazing. Bars represent means $\pm \mathrm{SD}$. 
changes in the no grazing, light grazing, and moderate grazing treatments and the difference among 3 treatments was not significant throughout the experiment period $(\mathrm{P}>0.05)$.

\section{Vegetation Cover, Canopy Height and Underground Biomass}

Mean vegetation cover, mean canopy height and mean root biomass decreased significantly with increasing grazing intensity with the largest decrease observed in the overgrazing treatment (Fig. 2). In the $5^{\text {th }}$ year, the mean vegetation cover, the mean canopy height, and the mean root biomass in the overgrazing treatment were $18 \%, 6 \%$, and $12 \%$ relative to the no grazing treatment, respectively.

\section{Aboveground Biomass}

Standing crop biomass decreased significantly with increasing grazing intensity (Table 2). The standing crop biomass decreased slightly with grazing time at both the overgrazing and moderate grazing treatments $(P>0.05)$ while it increased significantly with grazing time in the light grazing treatment. The standing crop biomass in the no grazing treatment increased from 1992 to 1994 and showed a decreasing trend afterwards. This might be due to litter accumulation, which restricted plant growth (Willms et al. 1986, Zhao et al. 1999). Difference of standing biomass caused by rainfall was not significant among years $(P>0.05)$ and the interaction between the treatments and annual rainfall on the standing biomass was also not significant among years $P>0.05$ ).

Net primary productivity in the 4 treatments did not change significantly with time ( $P>0.05$ ), but it decreased significantly with increasing grazing intensity (Table 2). Net primary productivity in the no grazing and light grazing treatments

Table 3. Live weight gain of average individual and total live weight gain of sheep in sandy grassland of Inner Mongolia as affected by grazing. Values are means \pm SD. Values with the same letters are not significantly different at $P \leq 0.05$.

\begin{tabular}{lcccccc}
\hline \hline \multicolumn{7}{c}{ Year } \\
Treatments & 1992 & 1993 & 1994 & 1995 & 1996 & Average \\
\hline \multicolumn{7}{c}{ Live weight gain of average individual $\left(\mathrm{kg} \mathrm{sheep}^{-1}\right)$} \\
Light grazing & $9.4 \pm 2.0$ & $8.2 \pm 3.8$ & $5.8 \pm 1.9$ & $10.7 \pm 5.1$ & $7.8 \pm 1.2$ & $8.4 \pm 1.9^{\mathrm{a}}$ \\
Mod. grazing & $9.4 \pm 2.2$ & $8.6 \pm 2.3$ & $6.3 \pm 2.3$ & $6.5 \pm 2.5$ & $5.7 \pm 1.8$ & $7.0 \pm 1.2 \mathrm{a}$ \\
Overgrazing & $2.4 \pm 3.1$ & $5.6 \pm 7.2$ & $-3.4 \pm 2.3$ & $-1.7 \pm 2.7$ & $-4.2 \pm 6.2$ & $-0.3 \pm 4.2 \mathrm{~b}$ \\
& \multicolumn{7}{c}{ Total live weight gain $\left(\mathrm{kg} \mathrm{ha}^{-1}\right)$} \\
Light grazing & $18.8 \pm 3.2$ & $16.4 \pm 3.2$ & $11.6 \pm 4.5$ & $21.4 \pm 3.5$ & $15.6 \pm 1.8$ & $16.8 \pm 4.0 \mathrm{ab}$ \\
Mod. grazing & $31.6 \pm 2.4$ & $34.4 \pm 2.9$ & $25.2 \pm 2.8$ & $26.0 \pm 3.1$ & $22.8 \pm 2.5$ & $28.0 \pm 5.1 \mathrm{a}$ \\
Overgrazing & $14.4 \pm 5.6$ & $33.6 \pm 3.2$ & $-20.4 \pm 10.7$ & $-10.2 \pm 4.6$ & $-25.2 \pm 7.2$ & $-1.6 \pm 26.8 \mathrm{~b}$ \\
\hline
\end{tabular}

was significantly higher than those in moderate grazing and overgrazing treatments. Net primary productivity was similar between the moderate grazing and overgrazing treatments except in the third year. Net primary productivity of the light grazing treatment exceeded that of the no grazing treatment in the $5^{\text {th }}$ year, although difference was not significant $(P>0.05)$ over the experimental period. Similarly, the difference of net primary productivity caused by rainfall was not significant among years $(P>0.05)$ and the interaction between the treatments and the effect of annual rainfall on the net primary production was also not significant among years $(\mathrm{P}>0.05)$.

\section{Liveweight Gain and Secondary Productivity}

Average liveweight gain per sheep was not significantly different $(P>0.05)$ between light grazing and moderate grazing treatments, but both were significantly higher than that in the overgrazing treatment during the experiment period. Average liveweight gain in the overgrazing treatment was positive in the first 2 years and became negative from the $3^{\text {rd }}$ year on (Table 3 ). Average annual-

Table 2. Standing crop biomass and net primary productivity in sandy grassland of Inner Mongolia as affected by grazing intensity. Values are means \pm SD. Values with the same letters are not significantly different at $\mathbf{P} \leq \mathbf{0 . 0 5}$.

\begin{tabular}{|c|c|c|c|c|c|c|}
\hline Treatments & 1992 & 1993 & $\begin{array}{c}\text { Year } \\
1993\end{array}$ & 1995 & 1996 & Average \\
\hline \multicolumn{7}{|c|}{ Standing biomass $\left(\mathrm{g} \mathrm{m}^{-2}\right)$} \\
\hline No grazing & $266 \pm 62$ & $347 \pm 271$ & $335 \pm 108$ & $220 \pm 58$ & $242 \pm 44$ & $282 \pm 57^{\mathrm{a}}$ \\
\hline Light grazing & $70 \pm 40$ & $117 \pm 33$ & $158 \pm 19$ & $192 \pm 47$ & $218 \pm 52$ & $151 \pm 59^{b}$ \\
\hline Mod. grazing & $98 \pm 75$ & $113 \pm 97$ & $86 \pm 87$ & $57 \pm 20$ & $67 \pm 40$ & $84 \pm 23^{c}$ \\
\hline Overgrazing & $38 \pm 16$ & $27 \pm 10$ & $24 \pm 37$ & $24 \pm 37$ & $3 \pm 6$ & $23 \pm 13^{d}$ \\
\hline \multicolumn{7}{|c|}{ Net primary productivity $\left(\mathrm{g} \mathrm{m}^{-2}\right)$} \\
\hline No grazing & $266 \pm 62$ & $347 \pm 272$ & $335 \pm 108$ & $220 \pm 58$ & $242 \pm 44$ & $282 \pm 57^{a}$ \\
\hline Light grazing & $199 \pm 43$ & $242 \pm 39$ & $280 \pm 91$ & $263 \pm 102$ & $246 \pm 102$ & $246 \pm 30^{b}$ \\
\hline Mod. grazing & $246 \pm 87$ & $212 \pm 118$ & $213 \pm 114$ & $127 \pm 41$ & $152 \pm 96$ & $190 \pm 49^{b}$ \\
\hline Ovérgrazing & $205 \pm 26$ & $187 \pm 24$ & $112 \pm 100$ & $155 \pm 149$ & $120 \pm 206$ & $156 \pm 41^{b}$ \\
\hline
\end{tabular}

liveweight gain was $8.4,7.0$, and $-0.3 \mathrm{~kg}$ sheep ${ }^{-1}$ in the light grazing, moderate grazing, and overgrazing treatments, respectively, during the 5-year experimental period (Table 3). The annual liveweight gain was $7.8,5.7$, and $-4.2 \mathrm{~kg} \mathrm{sheep}^{-1}$ in the light grazing, moderate grazing, and overgrazing treatments respectively in the $5^{\text {th }}$ year. Net secondary productivity in the moderate grazing and light grazing treatments was stable over the period and total productivity in the moderate grazing treatment $\left(140.0 \mathrm{~kg} \mathrm{ha}^{-1}\right)$ was higher than that in the light grazing treatment $\left(83.8 \mathrm{~kg} \mathrm{ha}^{-1}\right)$ in the 5-year experimental period. Accumulative live weight gain was -7.8 $\mathrm{kg} \mathrm{ha}^{-1}$ during the experimental period and was $-25.2 \mathrm{~kg} \mathrm{ha}^{-1}$ in the last year of the experiment in the overgrazing treatment.

\section{Discussion and Conclusions}

The 5-year grazing experiment indicates that overgrazing gave rise to a considerable decrease in plant species diversity and resulted in the species diversity to be significantly lower than that of other treatments in the last 3 years. The decrease in species diversity was closely related to the species richness. Species richness in overgrazing treatment decreased from 17-18 species to 14-7 species in the last 3 years. Ten species, including Pennisetum centrasiaticum, Phraomites communis, Cleistogensd squarrora (Trin.) Keng, Leymus secalinus, Setaria viridia, Aristida adscensionis, disappeared from the overgrazing plot in the last 3 years of the experiment, which resulted in a significant decrease in species diversity. Even unpalatable plants such as Eragrostis pilosa (L. ) Beauv, Chloris virgata Swartz and Artemisia scoparia Waldst. et Kit. decreased after overgrazing. Because the semi-arid sandy grassland in China is ecologically very fragile, overgrazing general- 


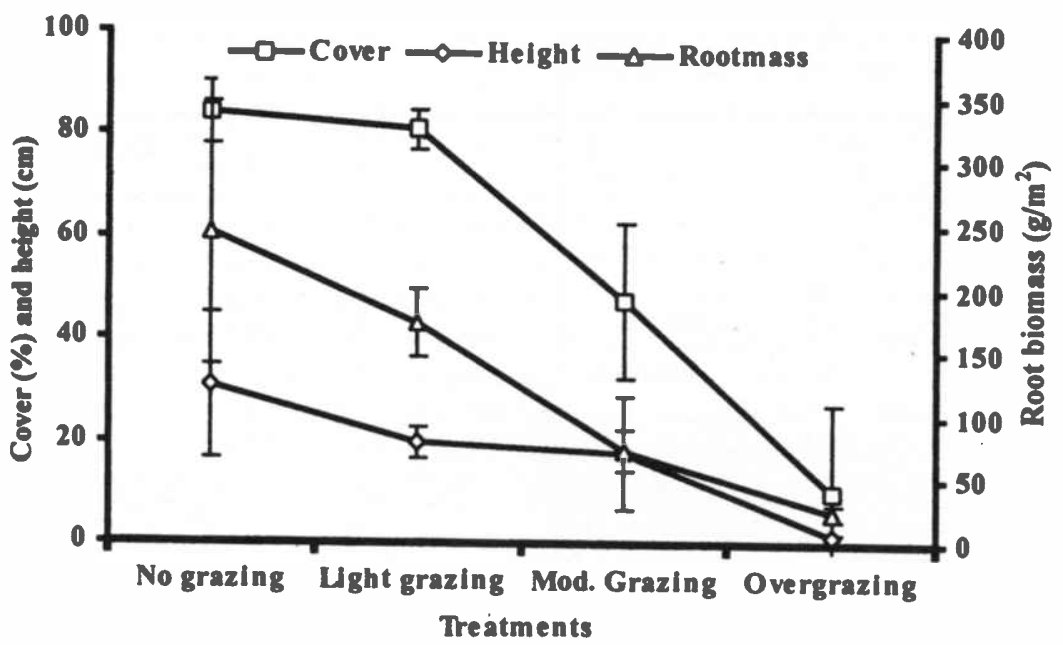

Fig. 2. Vegetation cover, canopy height, and belowground biomass in sandy grassland of Inner Mongolia as affected by grazing. Data were collected at the end of the 5-year experiment. Bars represent means $\pm \mathrm{SD}$.

ly restricts or reverses vegetation succession and finally results in a landscape with low plant species diversity (Zhu and Chen 1994).

Standing crop biomass and net primary productivity decreased significantly with increasing of grazing intensity. Such a large loss of the plant productivity in a short time period due to overgrazing is generally not observed in the zonal grassland of northeastern part of China (Wang et al. 1998). Average liveweight gain per sheep and net secondary productivity were not significantly different between light grazing and moderate grazing treatments during the experimental period, but they were significantly higher than that in the overgrazing treatment. Especially, the average liveweight gain per sheep and net secondary productivity had become negative and 2 sheep were dead in the overgrazing treatment in the $5^{\text {th }}$ year of the experiment. Therefore, we suggest that overgrazing should be stopped for the sustainable use of grassland. Vegetation cover, canopy height and belowground biomass decreased with an increase of grazing intensity. The ratio of bare soil surface in the overgrazing treatment reached up to $56.4 \%$ (Zhao 1997) was classified as severely desertified (Zhu 1998). Changes in soil texture and nutrition after overgrazing further indicate the occurrence of desertification (Zhang et al. 1998).

It is a challenge to efficiently utilize grassland resources without desertification in deteriorated semi-arid regions (Bethlenfalvay and Dakessian 1984, Zhao et al. 1999). Our grazing results indicate that light grazing is helpful in maintaining species diversity, below and aboveground biomass production, and animal production in the sandy grassland of Inner Mongolia. This is consistent with the observation in a typical steppe in Xilinguole, China (Wang et al. 1999). Christiansen and Svejcar (1998) also reported that light grazing favors progressive vegetation restoration and community stability of the deteriorated pasture. Li and (Wang (1999) and Li and Li (2000) argued that light grazing could keep an optimal yield of animal production in absence of deterioration of the grassland. Moderate grazing may have a risk of desertification in the dry and windy seasons (Zhao et al. 1999). Our conclusion is that the proper grazing intensity for the studied sandy grassland is $2-3$ sheep or sheep equivalents per hectare. The longer-term no grazing is not necessarily helpful for the sustainability of grassland ecosystem and the grazing can be used as long as vegetation can be recovered.

\section{Literature Cited}

Bethlenfalvay, G.T. and S. Dakessian. 1984. Grazing effects on mycorrhizal colonization and floristic composition of the vegetation on a semiarid range in northern Nevada. J. Range Manage. 37:312-316.

Christiansen, S. and T. Svejcar. 1988. Grazing effects on shoot and root dynamics and above and below-ground non-structural carbohydrate in Caucasian bluestem. Grass and Forage Sci.43:111-120.

Hu, M. C. 1996. Desertification trends of Horqin sandy land. p. 258-261. In: X.-M. Liu, H.-L. Zhao and A.-F. Zhao (eds) Windsandy environment and vegetation in the Horqin sandy land, China.Science Press, Beijing, China.(In Chinese)
Li, S.G., Y. Harazono, T. Oikawa, H. L. Zhao, Z. Y. He, and X. L. Chang. 2000. Grassland desertification by ,grazing and the resulting micrometeorological changes in Inner Mongolia. Agr. For. Meteorol. 102:125-137.

Li, W. L. and Z. Z. Li. 2000. The degradation mechanism of desert grassland and the counter measures for continued utilization of pastures. J. Lanzhou Univ. 36:161-169. (In Chinese)

Li, Y. H. and S. P. Wang. 1999. Response of plant and plant community to different stocking rates. Grassl. China 3:11-19. (In Chinese)

Shannon, C.E. and W. Weiner. 1949. The mathematical theory of communication. University Illinois Press, Urbana, Ill.

Sokal, R.R. and F.J. Rohlf. 1995. Biometry. W. H. Freeman, New York.

Wang, S.P., Z. Z. Chen, and Y. F. Wang. 1999. The study of optimal stocking rate and sustainable development of rangeland livestock Inner Mongolia steppe. Grassland of China. 4:67-75. (In Chinese)

Wang, S. P., Y. F. Wang, Y. H. Li, and Y. H. Han. 1998. The influence of different stoking rates on herbage regrowth and aboveground net primary production. Acta Agrestia Sinica. 6:275-281. (In Chinese).

Wang, T. 2000. Land use and sandy desertification in the north China. J. Desert Res. 20:103-113. (In Chinese).

Willms, W.D., S. Smoliak, and A.W. Bailey. 1986. Herbage production following litter removal on Alberta native grassland. J. Range Manage. 39:536-540.

Zhang, Q., X. Zhao, and H. L. Zhao. 1998. Grassland in sandy area, China. China Ocean Press, Beijing, China. (In Chinese)

Zhao, H. L. 1997. Desertification mechanism in Horqin sandy grazing grassland, Inner Mongolia. J. China Grassland. 3:15-23. (In Chinese).

Zhao, H. L. 1998. Enclosure results and its evaluation of degenerated grassland in Horqin sandy land. J. Desert Res. 18:46-50. (In Chinese).

Zhao, H. L., T. H. Zhang, and X. L. Chang. 1999. Cluster analysis on change laws of the vegetation under different grazing intensities in Horqin sandy pasture. J. Desert Res. 19:40-44. (In Chinese).

Zhu, Z.D. 1998. Desert, sand desertification and its rehabilitation in China. Environment Science Press, Beijing, China. 416 pp.

Zhu, Z. D. and G. T. Chen. 1994. Sandy desertification. Science Press, Beijing, China. $250 \mathrm{pp}$. (In Chinese) 